\title{
Antioxidant activity of selected parts of Prunus domestica L. harvested at two ripening stages
}

\author{
Anna Nowak ${ }^{1, A} \bowtie$, Dominika Szatan², Joanna Zielonka-Brzezicka1, Katarzyna Florkowska,, \\ Anna Muzykiewicz ${ }^{1, C}$, Adam Klimowicz ${ }^{1, D}$ \\ Pomeranian Medical University in Szczecin, Department of Cosmetic and Pharmaceutical Chemistry, Powstańców Wlkp. 72, 70-111 Szczecin, Poland \\ 2 Pomeranian Medical University in Szczecin, Graduate of Cosmetology, Powstańców Wlkp. 72, 70-111 Szczecin, Poland \\ A ORCID: 0000-0002-4287-6751; $\quad$ B ORCID: 0000-0002-6060-6472; C ORCID: 0000-0003-1880-1140; $\quad$ D ORCID: 0000-0001-6239-2853 \\ $\bowtie$ anowak@pum.edu.pl
}

\begin{abstract}
Introduction: Oxidative stress caused by an excess of reactive oxygen species (ROS) is the main reason behind many civilization diseases. The fruits and leaves of Prunus domestica L. contain antioxidants such as vitamins, polyphenols (including flavonoids) and organic acids.

The aim of the study was to evaluate the antioxidant activity and total polyphenol content of extracts of leaves and fruits of the plum harvested in 2 ripening phases.

Materials and methods: Antioxidative activity was measured by 2,2-diphenyl-1-picrylhydrazyl (DPPH) and 2,2'-azino-bis(3ethylbenzothiazoline-6-sulfonic acid) - ABTS methods, and total polyphenol content by Folin-Ciocalteu technique. Extracts in $40 \%, 70 \%$ and $96 \%(\mathrm{v} / \mathrm{v})$ of ethanol as well as $99.8 \%(\mathrm{v} / \mathrm{v})$ methanol were used. Ultrasound-assisted extraction was applied for 15,30 and $60 \mathrm{~min}$.
\end{abstract}

\section{INTRODUCTION}

Over the last few years there has been growing interest in healthy lifestyles, such as properly balanced diets with high antioxidant contents as well as supplements contained natural antioxidants $[1,2,3]$. It is suggested that more than half of the adult population living in highly developed countries consume such preparations. This may be partly due to the fact that a main cause of deaths in high-income countries are so-called civilization diseases with oxidative stress [4]. This phenomenon is associated with an excessive amount of free radicals from both endogenous and exogenous sources, leading to damage of important bodily structures, i.e. proteins, lipids or nucleic acids, and as a consequence, to the development of neurodegenerative diseases, i.e. Alzheimer's and Parkinson's disease, as well as initiating neoplastic process [5]. In addition, oxidative stress increases the risk of metabolic diseases such as diabetes. It may lead to damage in many organs and structures such as the lungs, kidneys, brain, eyes, joints and heart, resulting in asthma, chronic bronchitis, cataracts, heart failure, depression, rheumatism or atherosclerosis development. On one hand foetuses can be exposed to oxidative stress, and on the other hand it may accelerate aging [6].
Results: The antioxidant potential of the extracts, measured by DPPH method, was highest for leaf methanolic extracts of plum harvested before ripening $(3.83 \pm 0.01 \mathrm{mg}$ trolox/g of raw material), while for the ABTS method, highest activity was found in the fruit peel extract in methanol $(12.89 \pm 0.04 \mathrm{mg}$ trolox/g raw material). The highest polyphenol levels ( $5.89 \pm 0.16,6.06 \pm 0.09$ and $5.76 \pm 0.13 \mathrm{mg}$ gallic acid/g raw material) were found in the extracts of leaves harvested at fruit ripening stage, prepared in $70 \%$ (30 and $60 \mathrm{~min}$ ) ethanol and $40 \%$ ethanol ( $60 \mathrm{~min})$, respectively. Conclusion: The alcohol based extracts from the leaves and fruit of Prunus domestica L. were characterized by high antioxidant potential, which suggests the possibility of their use as a valuable source of antioxidants. Ethanol seems to be the most appropriate extractant.

Keywords: alcohol based extracts; antioxidant activity; Prunus domestica L.; ripening stage; total polyphenol content.
Proper diets, rich in vegetables and fruits, can reduce the incidence of chronic diseases related to oxidative stress [7]. One fruit rich in phytoconstituents with antioxidant activity is the plum. Prunus domestica L. (subfamily Prunoidae) often grows in countries with a temperate climatic, such as Europe. It is assumed that about half of the crop yield is consumed as fresh fruit [3], while the remaining part is processed [8]. Plums are frequently used in the production of alcohol beverages (such as slivovitz), frozen food, jams, marmalades, compotes, marinades, and dried fruit. The largest world producer of plums is China, and in Europe - Romania, France, Spain and Italy. In Poland the plum is grown only in several regions due to the specific climatic conditions required [9]. Plums are a source of health benefiting nutrients and compounds, are rich in organic acids (e.g. malic and citric acid), carbohydrates, pectins, tannins, as well as enzymes. They are also a valuable source of several phenolic compounds considered to be natural antioxidants. Plums are characterized by a higher antioxidant activity than other commonly consumed fruits, such as apples, strawberries and oranges, as well as vitamin $\mathrm{C}$, a potent antioxidant [8]. Plum seeds are rich in oils with a high content of unsaturated fatty acids, phytosterols and tocopherols [10]. Also, the leaves 
seem to be a valuable source of antioxidants [11]. The healthpromoting potential of Prunus domestica L. has been the subject of numerous studies, and due to the above-mentioned properties this fruit is widely consumed.

The aim of the study was to evaluate the antioxidant activity and total polyphenol content of aqueous-alcohol based extracts of plum leaves and fruit from 2 ripening stages.

\section{MATERIALS AND METHODS}

2,2-diphenyl-1-picrylhydrazyl (DPPH), 2,2'-azino-bis(3-ethylbenzothiazoline-6-sulfonic acid) - ABTS, $( \pm)$-6-hydroxy-2,5,7,8tetramethylchromane-2-carboxylic acid (trolox) were supplied by Sigma Aldrich, USA; gallic acid (GA), Folin-Ciocalteu reagent by Merck, Darmstadt, Germany; anhydrous sodium carbonate by Loba Chemie, India; and ethyl and methyl alcohols by Chempur, Piekary Śląskie, Poland. All reagents were of analytical grade purity.

The raw material from self-harvesting in Szczecin ( $53^{\circ} 26^{\prime} 29^{\prime \prime} \mathrm{N}$, $14^{\circ} 30^{\prime} 54^{\prime \prime} \mathrm{E}$ ) consisted of leaves, fruit and peel of Mirabelle plums (Prunus domestica L.) harvested in 2 growing periods - June, before the fruit ripening stage, and September, during fruit ripening. Ultrasound-assisted extraction (at $40 \mathrm{kHz}$ ) was applied for 15, 30 and 60 min to obtain extracts with $40 \%$ (v/v), $70 \%(\mathrm{v} / \mathrm{v})$ and $96 \%(\mathrm{v} / \mathrm{v})$ ethanol and $99.8 \%(\mathrm{v} / \mathrm{v})$ methanol.

Antioxidant potential was evaluated using DPPH and ABTS methods, while total polyphenol content was determined by Folin-Ciocalteu method, as described in literature $[7,12,13$, 14]. For the DPPH and ABTS methods ( \pm )-6-hydroxy-2,5,7,8tetramethylchromane-2-carboxylic acid (trolox) was used as a reference. The results were expressed as a trolox equivalent antioxidant capacity - TEAC (mg trolox/g raw material) as well as radical scavenging activity - RSA (\%). For total polyphenol determination, GA was used as a reference and the results expressed as gallic acid equivalents - GAE (mg GA/g raw material). Results are presented as arithmetical means \pm standard deviation (SD).

Statistical analysis of the results was done with ANOVA at the significance $p=0.05$. The significance of differences between particular results was assessed using a Tukey test $(n=3)$. Mean values marked by different letters differed significantly taking into account all solvents applied. Statistical calculations were done using Statistica 12 PL software (StatSoft, Polska).

\section{RESULTS}

Tables 1, 2, 3 show the antioxidant activity and total polyphenol content of the various extracts made from plum leaves, fruit and peel, in the 2 respective growing stages. Figures $1 \mathrm{a}$ and $1 \mathrm{~b}$ present the RSA. Statistical differences between the extract solvent used and length of of extraction time were evaluated.

Antioxidant activity evaluated by DPPH method is presented in Table 1. The antioxidant potential of the extracts varied from $0.73 \pm 0.01$ TEAC (mg trolox/g raw material) for plum fruit harvested before ripening and extracted in $40 \%$ ethanol for $30 \mathrm{~min}$, to $3.83 \pm 0.01$ TEAC for plum leaves harvested before ripening and extracted in methanol for $15 \mathrm{~min}$. The antioxidant activity determined by DPPH method of the extracts of plum leaves was high. For the 1st season, the highest value was found for methanolic extracts $(3.83 \pm 0.01$ TEAC) and at the 2nd harvesting stage for extracts prepared in $96 \%$ ethanol for $60 \mathrm{~min}$ ( $3.82 \pm 0.02 \mathrm{TEAC}$ ). Antioxidant potential of ripe fruit, evaluated using DPPH method, was significantly higher as compared to unripe fruit, the highest results for this plant part was found for extracts prepared in $70 \%$ ethanol for $60 \min -3.60 \pm 0.01$ TEAC - Table 1 .

TABLE 1. Antioxidant properties of plum leaf, fruit and peel extracts evaluated using DPPH, expressed as trolox equivalent antioxidant capacity (mg trolox/g raw material; mean \pm standard deviation)

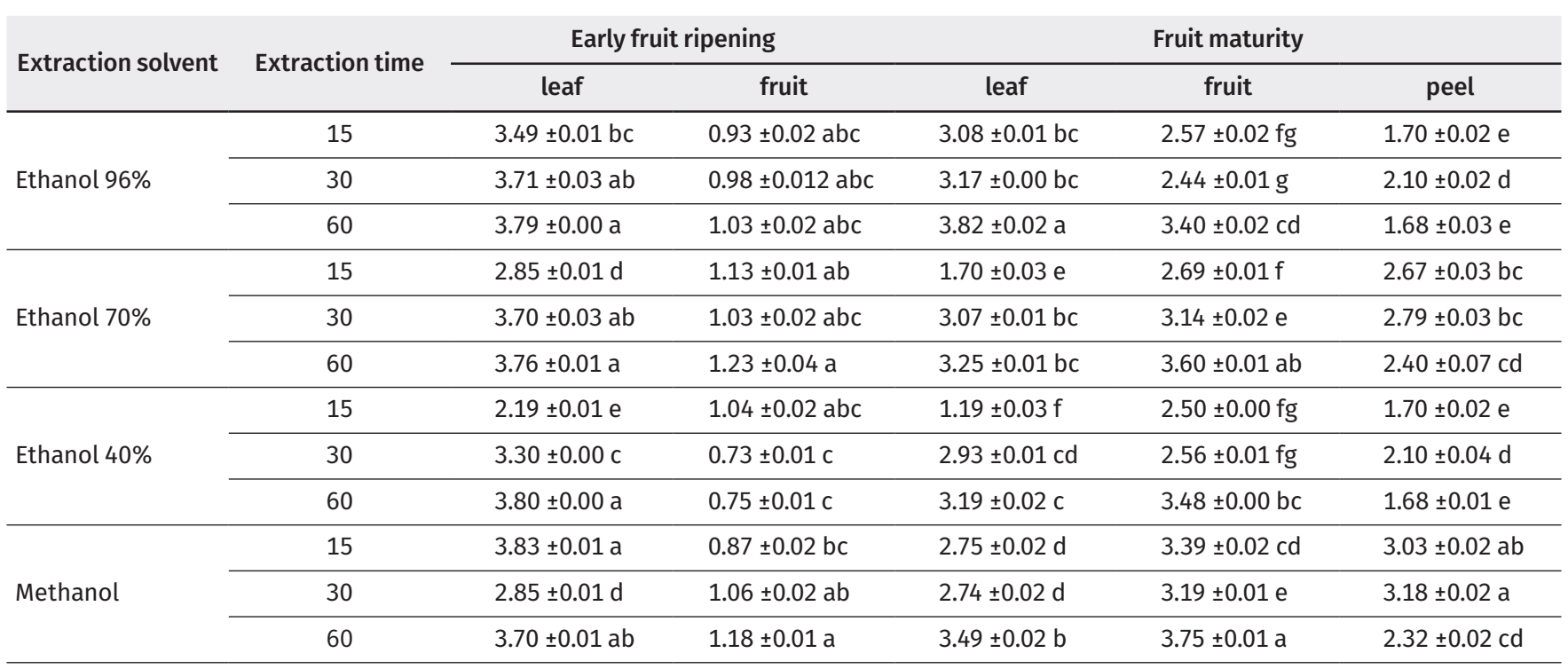

Mean values marked by different letters differed significantly considering the extraction solvent. Significance level $\alpha=0.05 ; n=3$ 
Table 2 presents the antioxidant activity of plum extracts evaluated by ABTS. The results ranged from $0.17 \pm 0.02$ TEAC (mg trolox/g raw material) for unripe fruit extracted for $15 \mathrm{~min}$ in $40 \%(\mathrm{v} / \mathrm{v})$ ethanol, to $12.89 \pm 0.04$ TEAC for fruit peel extracted for $60 \mathrm{~min}$ in methanol. Antioxidant potential evaluated by ABTS method was highest for peel extracts in methanol, regardless of extraction time, at $12.62 \pm 0.03,12.74$ \pm 0.03 and $12.89 \pm 0.04$ TEAC for 15,30 and 60 min of extraction, respectively.

Similar high results were found for plum peel extracts in other extractants. Extracts of plum leaves harvested before fruit ripening also showed high antioxidant activity, especially those extracted for $60 \mathrm{~min}(8.44 \pm 0.02 \mathrm{TEAC})$. As in the case of the DPPH method, the mature fruit extracts showed a significantly higher antioxidant activity - Table 2.
Table 3 presents the total polyphenol content in various extracts. Results ranged between $0.47 \pm 0.09 \mathrm{GAE}$ (mg GA/g raw material) for unripe plum fruit extracted for $15 \mathrm{~min}$ in $40 \%$ ethanol, to 6.06 $\pm 0.09 \mathrm{GAE}$ for plum leaves harvested at fruit maturing season, extracted for $60 \mathrm{~min}$ in $70 \%$ ethanol. The highest values were for plum leaf extracts harvested in maturity prepared in 70\% ethanol (30 and $60 \mathrm{~min}$ ) and 40\% ethanol (60 min) - $5.89 \pm 0.16$, $6.06 \pm 0.09$ and $5.76 \pm 0.13 \mathrm{GAE}$, respectively. For peel extracts, the highest polyphenol content was found for extracts in $96 \%$ ethanol (extraction time $60 \mathrm{~min}$ ) $-4.38 \pm 0.16 \mathrm{GAE}$ and in methanol ( 30 and $60 \mathrm{~min})-4.36 \pm 0.18$ and $4.21 \pm 0.16 \mathrm{GAE}$, respectively. The lowest values for plum fruit were found in both immature and mature, regardless of the extraction time, while the highest content was found in unripe plum fruit extracted in methanol, which differed significantly from the other samples - Table 3.

TABLE 2. Antioxidant properties of plum leaf, fruit and peel extracts evaluated using ABTS, expressed as trolox equivalent antioxidant capacity (mg trolox/g raw material; mean \pm standard deviation)

\begin{tabular}{|c|c|c|c|c|c|c|}
\hline \multirow{2}{*}{ Extraction solvent } & \multirow{2}{*}{ Extraction time } & \multicolumn{2}{|c|}{ Early fruit ripening } & \multicolumn{3}{|c|}{ Fruit maturity } \\
\hline & & leaf & fruit & leaf & fruit & peel \\
\hline \multirow{3}{*}{ Ethanol $96 \%$} & 15 & $4.26 \pm 0.05 \mathrm{e}$ & $1.30 \pm 0.01 \mathrm{c}$ & $3.33 \pm 0.03 c$ & $4.22 \pm 0.03 a b c$ & $9.54 \pm 0.01 b c$ \\
\hline & 30 & $5.64 \pm 0.03 d$ & $2.27 \pm 0.05 b$ & $3.36 \pm 0.04 c$ & $4.81 \pm 0.03 a b$ & $10.03 \pm 0.02 b$ \\
\hline & 60 & $6.81 \pm 0.01 \mathrm{c}$ & $3.46 \pm 0.04 \mathrm{a}$ & $4.02 \pm 0.04 b$ & $5.04 \pm 0.03 \mathrm{a}$ & $10.21 \pm 0.03 b$ \\
\hline \multirow{3}{*}{ Ethanol $70 \%$} & 15 & $4.16 \pm 0.04$ & $0.24 \pm 0.01 \mathrm{~d}$ & $1.87 \pm 0.03 \mathrm{~d}$ & $3.77 \pm 0.03 a b c$ & $8.59 \pm 0.03 \mathrm{~cd}$ \\
\hline & 30 & $4.53 \pm 0.02 \mathrm{e}$ & $0.46 \pm 0.04 \mathrm{~d}$ & $2.40 \pm 0.05 \mathrm{~d}$ & $4.27 \pm 0.01 \mathrm{abc}$ & $8.80 \pm 0.03 \mathrm{~cd}$ \\
\hline & 60 & $5.60 \pm 0.03 d$ & $2.55 \pm 0.03 b$ & $3.24 \pm 0.03 c$ & $4.57 \pm 0.01 \mathrm{abc}$ & $9.18 \pm 0.02 b c$ \\
\hline \multirow{3}{*}{ Ethanol $40 \%$} & 15 & $3.54 \pm 0.04 \mathrm{f}$ & $0.17 \pm 0.02 \mathrm{~d}$ & $0.70 \pm 0.05 \mathrm{e}$ & $3.24 \pm 0.06 \mathrm{~d}$ & $7.25 \pm 0.05 f$ \\
\hline & 30 & $4.21 \pm 0.05 \mathrm{e}$ & $1.18 \pm 0.04 \mathrm{C}$ & $1.01 \pm 0.05 \mathrm{e}$ & $3.42 \pm 0.05 \mathrm{~cd}$ & $7.57 \pm 0.02 \mathrm{de}$ \\
\hline & 60 & $5.26 \pm 0.03 d$ & $2.30 \pm 0.01 b$ & $3.20 \pm 0.03 c$ & $3.35 \pm 0.04 \mathrm{~cd}$ & $7.77 \pm 0.03 \mathrm{de}$ \\
\hline \multirow[t]{2}{*}{ Methanol } & 30 & $7.72 \pm 0.04 b$ & $2.25 \pm 0.05 b$ & $6.03 \pm 0.03 a$ & $4.30 \pm 0.04 \mathrm{abc}$ & $12.74 \pm 0.03 \mathrm{a}$ \\
\hline & 60 & $8.44 \pm 0.02 \mathrm{a}$ & $3.70 \pm 0.04 \mathrm{a}$ & $6.23 \pm 0.02 \mathrm{a}$ & $4.51 \pm 0.04 a b c$ & $12.89 \pm 0.04 \mathrm{a}$ \\
\hline
\end{tabular}

Mean values marked by different letters differed significantly considering the extraction solvent. Significance level $\alpha=0.05 ; n=3$

TABLE 3. Total polyphenol content of plum leaf, fruit and peel extracts evaluated using Folin-Ciocalteu method, expressed as gallic acid equivalents (mg gallic acid/g raw material; mean \pm standard deviation)

\begin{tabular}{|c|c|c|c|c|c|c|}
\hline \multirow{2}{*}{ Extraction solvent } & \multirow{2}{*}{ Extraction time } & \multicolumn{2}{|c|}{ Early fruit ripening } & \multicolumn{3}{|c|}{ Fruit maturity } \\
\hline & & leaf & fruit & leaf & fruit & peel \\
\hline \multirow{3}{*}{ Ethanol $96 \%$} & 15 & $2.55 \pm 0.13 \mathrm{f}$ & $0.78 \pm 0.09$ def & $3.69 \pm 0.12 f$ & $0.99 \pm 0.12 \mathrm{de}$ & $3.15 \pm 0.15 \mathrm{e}$ \\
\hline & 30 & $3.15 \pm 0.07 \mathrm{~d}$ & $0.90 \pm 0.07 \mathrm{de}$ & $4.21 \pm 0.12 \mathrm{de}$ & $1.03 \pm 0.14 \mathrm{cde}$ & $3.70 \pm 0.07 \mathrm{~cd}$ \\
\hline & 60 & $4.60 \pm 0.06 b$ & $1.05 \pm 0.11 \mathrm{~d}$ & $4.38 \pm 0.05 \mathrm{~d}$ & $1.48 \pm 0.12 b$ & $4.38 \pm 0.16 \mathrm{a}$ \\
\hline \multirow{3}{*}{ Ethanol $70 \%$} & 15 & $1.15 \pm 0.07 \mathrm{~g}$ & $0.55 \pm 0.06 \mathrm{fg}$ & $3.71 \pm 0.07 \mathrm{f}$ & $0.87 \pm 0.08 \mathrm{def}$ & $3.12 \pm 0.01 \mathrm{e}$ \\
\hline & 30 & $2.90 \pm 0.12 \mathrm{de}$ & $0.63 \pm 0.15$ efg & $5.89 \pm 0.16 a b$ & $1.11 \pm 0.05 \mathrm{~cd}$ & $3.50 \pm 0.04 \mathrm{~d}$ \\
\hline & 60 & $4.17 \pm 0.04 \mathrm{C}$ & $1.00 \pm 0.09 \mathrm{~d}$ & $6.06 \pm 0.09 a$ & $1.45 \pm 0.07 \mathrm{~b}$ & $3.82 \pm 0.07 \mathrm{~cd}$ \\
\hline \multirow{3}{*}{ Ethanol $40 \%$} & 15 & $2.85 \pm 0.09 \mathrm{e}$ & $0.47 \pm 0.09 \mathrm{~g}$ & $4.79 \pm 0.09 c$ & $0.67 \pm 0.12 \mathrm{f}$ & $1.40 \pm 0.13 f$ \\
\hline & 30 & $4.23 \pm 0.12 c$ & $0.55 \pm 0.11 \mathrm{fg}$ & $5.57 \pm 0.20 b$ & $0.80 \pm 0.09$ ef & $1.45 \pm 0.012 \mathrm{f}$ \\
\hline & 60 & $5.37 \pm 0.07 a$ & $0.81 \pm 0.08 \mathrm{de}$ & $5.76 \pm 0.13 a b$ & $0.92 \pm 0.14$ def & $1.39 \pm 0.13 \mathrm{f}$ \\
\hline \multirow[t]{2}{*}{ Methanol } & 30 & $4.89 \pm 0.14 b$ & $2.74 \pm 0.12 b$ & $3.91 \pm 0.08$ ef & $1.54 \pm 0.07 \mathrm{ab}$ & $4.36 \pm 0.18 \mathrm{a}$ \\
\hline & 60 & $5.65 \pm 0.15 a$ & $3.31 \pm 0.13 \mathrm{a}$ & $4.12 \pm 0.12 \mathrm{de}$ & $1.79 \pm 0.07 \mathrm{a}$ & $4.21 \pm 0.16 a b$ \\
\hline
\end{tabular}

Mean values marked by different letters differed significantly considering the extraction solvent. Significance level $\alpha=0.05 ; n=3$ 
Figures $1 \mathrm{a}$ and $1 \mathrm{~b}$ shows the percentage of free RSA of plum fruit and leaf extracts, determined by DPPH method, harvested in each of the growing seasons. The ripe plum fruit extracts showed a higher \%RSA. For all the solvents applied, the highest RSA was observed for the longest extraction time (60 min): $79.5 \pm 0.5 \%$ RSA (ethanol 40\%), $81.9 \pm 2.1 \%$ RSA (ethanol 70\%), $77.7 \pm 2.2 \%$ RSA (ethanol 96\%) and $85.0 \pm 1.1 \%$ RSA (methanol). In the case of the leaf extracts, the \%RSA was higher for the samples harvested before fruit ripening, however, high values exceeding $80 \%$ RSA were usually observed in extracts with longer extraction times (Fig. $1 \mathrm{a}, \mathrm{b}$ ).
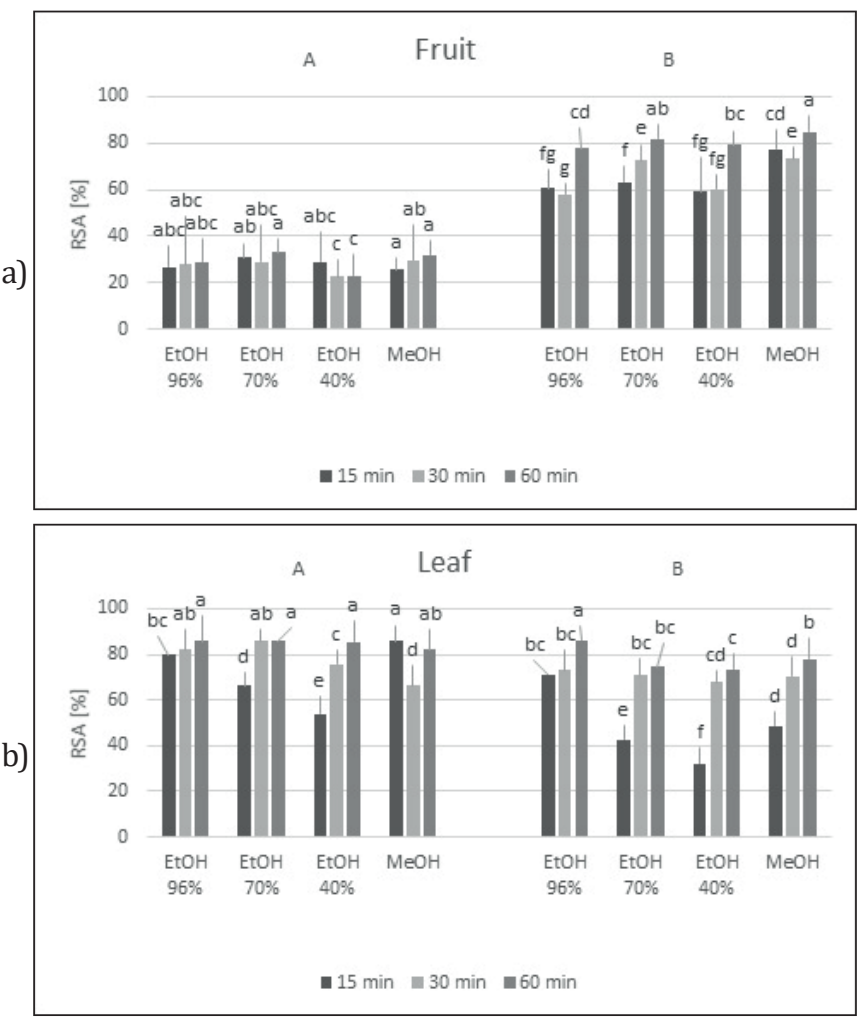

FIGURE 1. Mean radical scavenging activity of Prunus domestica L. extracts of plum fruit and leaf harvested at early fruit ripening (a) and fruit maturity (b), evaluated by DPPH method

\section{DISCUSSION}

Plum fruit is a valuable material containing a number of health beneficial compounds used primarily in the food industry, where both fresh and dried fruits could be applied. Plum fruit is rich in nutritionally valuable compounds, i.e. polyphenols, minerals, pectins and vitamins. Other parts of Prunus domestica L., for example the leaves, are also useful materials with high antioxidant activity due to the content of active substances such as polyphenols, such as flavonoids. A few reports have been published on the possibility of using raw materials derived from this plant, not just in the food industry but also in the cosmetic industry [15]. The high antioxidant activity should also be taken into account in preparations applied to the skin, as this tissue can be also exposed to oxidative stress caused, for example, by excessive UV radiation [16].
In our study, high antioxidant activity as well as high total polyphenol content in extracts of different Prunus domestica L. parts have been confirmed, depending on the type of raw material, the solvent used and the extraction time. In the case of DPPH method, the highest value of $3.83 \pm 0.01$ TEAC was found for extracts of leaf harvested at early ripening stage after 15 min extraction in methanol. This value corresponded to a free radicals scavenging activity of $85.8 \pm 0.9 \%$ RSA. Similar results were obtained by Morabbi Najafabad and Jamei who compared fresh and dried plum fruit growing in Iran. They used undiluted methanol and ethanol as extraction solvents and found antioxidant potentials of $49 \%$ RSA and $62 \%$ RSA for ethanol and methanol based extracts, respectively. For the dried plum extracts in the same solvents the activity was higher - about $79 \%$ and $87 \%$ RSA, respectively [17]. In our study, only fresh fruits were used, which resulted in lower antioxidant activity. The drying process can have a significant impact on this parameter as even drying at $80-90^{\circ} \mathrm{C}$ can increase the antioxidant effect of the raw material in terms of dry weight $[18,19,20]$.

Phenolic compounds are considered one of the most valuable antioxidants in the human diet. They neutralize free radicals and could reduce the development of many diseases [21]. Plum raw materials, such as fruit or leaves, are a rich source of antioxidant substances [15]. Total polyphenol content in different plum varieties ranged between $282 \mathrm{mg} / 100 \mathrm{~g}$ and $922 \mathrm{mg} / 100 \mathrm{~g}$ fruit [17]. Anthocyanins, responsible for fruit pigmentation, are also valuable antioxidants [22].

In our study, the total polyphenol content depended on the individual part of the plant. The highest concentration was usually found in the leaf extracts. In the case of leaves harvested at late ripening, polyphenol content was highest in the extracts in $70 \%$ ethanol (30 min) - 6.06 \pm 0.09 GAE (Tab. 3). Mocan et al. analyzed the total polyphenol content in the leaves of 7 pear cultivars using a water:methanol solution (30:70) as a solvent. The concentration ranged from $82.8 \mathrm{mg} \mathrm{GA} / \mathrm{g}$ extract for the Carpatin variety, to $139.7 \mathrm{mg} \mathrm{GA} / \mathrm{g}$ extract for the Ialomiţa variety. These results corresponded to antioxidant activity measured by DPPH and ABTS: for the Carpatin variety $1.83 \mathrm{mmol}$ trolox/g extract by the DPPH method, 394.42 mg trolox/g extract by the ABTS method, and for the Ialomiţa variety, $3.42 \mathrm{mmol}$ trolox/g extract by DPPH and $481.60 \mathrm{mg}$ trolox/g extract by ABTS [21]. Moreover, Singh et al. found the total polyphenol content in 2 species of plum fruits growing in Himalayan region of India, i.e. P. domestica and P. pyrifolia, of 145.56 and $159.86 \mu \mathrm{g} \mathrm{GA} / \mathrm{mL}$, respectively [23].

The fruit composition may differ, depending on such factors as the natural environment, growing conditions, as well as the fruit maturity stage [24]. Differences in the active substance content as well as antioxidant potential can be also observed between the plants part. In our study, plum fruit peel and leaves were the most valuable raw materials from the whole fruit. The high content of valuable substances in the fruit peel was confirmed by Navarro et al., who observed a higher total polyphenol content in the peel than in the pulp of plums growing in Costa Rica [25]. In the study by Walkowiak-Tomczak, the anthocyanin content in the skin of the plum fruit significantly exceeded the content in the fruit pulp. These substances are considered valuable antioxidants [19]. In 
our study, fruit harvested at a mature stage showed higher antioxidant activity compared to unripe fruit. It may suggest that deeply coloured fruit is a rich source of polyphenols, including flavonoids [17], therefore fully mature fruit with a dark skin may show high antioxidant activity [26].

During the growing seasons, the chemical composition of the plants changed, and this phenomenon is reflected in their antioxidant activity $[22,27,28]$. Taking into account the antioxidant potential of the leaves, the antioxidant activity was higher in the 1st growing stage (Fig. 1b). This observation was confirmed by Stierlin et al. They evaluated the antioxidant activity of some content in the leaves of young trees before fruiting (6-7-years-old) with leaves of fruiting trees (over 7-years-old). The antioxidant activity measured by DPPH method was slightly higher in the leaves from young trees [15]. On the other hand, Wang and Lin observed reduced antioxidant activity and lower polyphenol content in the leaves of red raspberries (Rubus idaeus), black raspberries (Rubus occidentalis), and strawberries (Fragaria $\times$ ananassa) with plant aging [29].

\section{CONCLUSION}

Prunus domestica L. fruits are a valuable material with high antioxidant properties which may play a significant role in daily health protection. Ethanol seems to be the most appropriate extractant. Proper material selection taking into account the plant growth stage as well as extraction conditions may be helpful in obtaining intermediate products with higher antioxidant potential to be used in the pharmaceutical and cosmetic industries.

\section{REFERENCES}

1. Harasym J, Oledzki R. Effect of fruit and vegetable antioxidants on total antioxidant capacity of blood plasma. Nutrition 2014;30(5):511-7. doi: 10.1016/j.nut.2013.08.019.

2. Schillaci C, Nepravishta R, Bellomaria A. Antioxidants in food and pharmaceutical research. AJ Ph Sci 2013;1(1):9-15.

3. Sut S, Dall'Acqua S, Poloniato G, Maggi F, Malagoli M. Preliminary evaluation of quince (Cydonia oblonga Mill.) fruit as extraction source of antioxidant phytoconstituents for nutraceutical and functional food applications. J Sci Food Agric 2019;99(3):1046-54. doi: 10.1002/jsfa.9271.

4. Bjelakovic G, Nikolova D, Gluud C. Antioxidant supplements and mortality. Curr Opin Clin Nutr Metab Care 2014;17(1):40-4. doi: 10.1097/ MC0.0000000000000009.

5. Poprac P, Jomova K, Simunkova M, Kollar V, Rhodes CJ, Valko M. Targeting free radicals in oxidative stress-related human diseases. Trends Pharmacol Sci 2017;38(7):592-607. doi: 10.1016/j.tips.2017.04.005.

6. Asmat U, Abad K, Ismail K. Diabetes mellitus and oxidative stress A concise review. Saudi Pharm J 2016;24(5):547-53. doi: 10.1016/j. jsps.2015.03.013.

7. Nowak A, Zielonka-Brzezicka J, Klimowicz A, Wira D, Wysocka D, Grzesiak K, et al. Aktywność antyoksydacyjna alkoholowych ekstraktów męczennicy jadalnej (Passiflora edulis Sims.) i hurmy wschodniej (Diospyros kaki L.). Probl Hig Epidemiol 2018;99(4):336-43.

8. Nisar H, Ahmed M, Anjum MA, Hussain S. Genetic diversity in fruit nutritional composition, anthocyanins, phenolics and antioxidant capacity of plum (Prunus domestica) genotypes. Acta Sci Pol Hortorum Cultus 2015;14(1): 45-61.
9. Michalska A, Łysiak G. Przydatność do suszenia owoców śliw uprawianych w Polsce w aspekcie przemian związków bioaktywnych i tworzących się produktów reakcji Maillarda. Żywn Nauka Technol Jakość 2014;6(97):29-38.

10. Dulf FV, Vodnar DC, Socaciu C. Effects of solid-state fermentation with two filamentous fungi on the total phenolic contents, flavonoids, antioxidant activities and lipid fractions of plum fruit (Prunus domestica L.) by-products. Food Chem 2016;209:27-36. doi: 10.1016/j.foodchem.2016.04.016.

11. Gougoulias N. Evaluation of antioxidant activity and polyphenol content of leaves from some fruit species. Oxid Commun 2015;38(1):35-45.

12. Muzykiewicz A, Zielonka-Brzezicka J, Klimowicz A. Antioxidant potential of Hippophae rhamnoides L. extracts obtained with green extraction technique. Herba Pol 2018;64(4):14-22. doi: 10.2478/hepo-2018-0022.

13. Nowak A, Zielonka-Brzezicka J, Pechaiko D, Tkacz M, Klimowicz A. Ocena właściwości antyoksydacyjnych liści Ginkgo biloba L. po zakończeniu wegetacji. Pomeranian J Life Sci 2017;63(1):24-30. doi: 10.21164/pomjlifesci.222.

14. Zielonka-Brzezicka J, Nowak A, Klimowicz A, Duchnik W, Wira D, Wysocka D, et al. Ocena aktywności antyoksydacyjnej ananasa jadalnego (Ananas comosus). Pomeranian J Life Sci 2018;64(3):132-8. doi: 10.21164/pomjlifesci.456.

15. Stierlin E, Azoulay S, Massi L, Fernandez X, Michel T. Cosmetic potentials of Prunus domestica L. leaves. J Sci Food Agric 2018;98(2):726-36. doi: $10.1002 /$ jsfa.8520

16. Nowak A, Zielonka J, Turek M, Klimowicz A. Wpływ przeciwutleniaczy zawartych w owocach na proces fotostarzenia się skóry. Post Fitoter 2014;15(2):94-9.

17. Morabbi Najafabad A, Jamei R. Free radical scavenging capacity and antioxidant activity of methanolic and ethanolic extracts of plum (Prunus domestica L.) in both fresh and dried samples. Avicenna J Phytomed 2014;4(5):343-53.

18. Piga A, Del Caro A, Corda G. From plums to prunes: influence of drying parameters on polyphenols and antioxidant activity. J Agric Food Chem 2003;51(12):3675-81.

19. Walkowiak-Tomczak D. Wpływ stopnia dojrzałości na parametry fizyczno-chemiczne i zawartość związków polifenolowych w wybranych odmianach śliwek (Prunus domestica). Nauka Przyr Technol 2009;3(4):149-58.

20. Michalska A, Wojdyło A, Łysiak GP, Figiel A. Chemical composition and antioxidant properties of powders obtained from different plum juice formulations. Int J Mol Sci 2017;18(1): pii: E176. doi: 10.3390/ijms18010176.

21. Mocan A, Diuzheva A, Carradori S, Andruch V, Massafra C, Moldovan C, et al. Development of novel techniques to extract phenolic compounds from Romanian cultivars of Prunus domestica L. and their biological properties. Food Chem Toxicol 2018;119:189-98. doi: 10.1016/j.fct.2018.04.045.

22. Kim S, Kim M, Cho S, Kim S, Kim J, Cho Y. Antioxidant activities and determination of phenolic compounds isolated from oriental plums (Soldam, Oishiwase and Formosa). Nutr Res Pract 2012;6(4):277-85. doi: 10.4162/ nrp.2012.6.4.277.

23. Singh M, Chauhan PK, Kumar V, Kour J. Assessment of phytochemical and antioxidant potential of underutilized pear (Pyrus pyrifolia) and plum (Prunus domestica) from indigenous Himalayan region of Himachal Pradesh. Int J Pharm Sci Res 2017;8(7):2982-7. doi: 10.13040/IJPSR.0975-8232.8(7).2982-87.

24. Głowacka A, Rozpara E. Growth, yielding and fruit quality of four plum (Prunus domestica L.) cultivars under organic orchard conditions. J Research Applic Agr Eng 2014;59(3):56-60.

25. Navarro M, Moreira I, Arnaez E, Quesada S, Azofeifa G, Vargas F, et al. Polyphenolic characterization and antioxidant activity of Malus domestica and Prunus domestica cultivars from Costa Rica. Foods 2018;7(2). pii: E15. doi: 10.3390/foods7020015.

26. Crisosto $\mathrm{CH}$, Bremer V, Ferguson L, Crisosto GM. Evaluating quality attributes of four fresh fig (Ficus carica L.) cultivars harvested at two maturity stages. Hort Sci 2010;45(4):707-10. doi: 10.21273.HORTSCI.45.4.707.

27. Katalinic V, Mozina SS, Generalic I, Skroza D, Ljubenkov I, Klancnik A. Phenolic profile, antioxidant capacity and antimicrobial activity of leaf extracts from six Vitis vinifera L. varieties. Int J Food Prop 2013;16:45-60. doi: 10.1080/10942912.2010.526274.

28. Walkowiak-Tomczak D, Biegańska-Marecik R, Reguła J. Aktywność przeciwutleniająca wybranych odmian śliwek (Prunus domestica) uprawianych w kraju. Żywn Nauka Technol Jakość 2007;6(55):109-15.

29. Wang SY, Lin HS. Antioxidant activity in fruits and leaves of blackberry, raspberry, and strawberry varies with cultivar and developmental stage. J Agric Food Chem 2000;48(2):140-6. doi: 10.1021/jf9908345. 